\title{
ADDITIONAL OBSERVATIONS ON THE LATE PROTEROZOIC VARANGERFJORDEN UNCONFORMITY, FINNMARK, NORTHERN NORWAY
}

\author{
KAUKO LAAJOKI
}

LAAJOKI, KAUKO 2001. Additional observations on the late Proterozoic Varangerfjorden unconformity, Finnmark, northern Norway. Bulletin of the Geological Society of Finland 73, Parts 1-2, 17-34.

This paper is complementary to the author's recent publication, which provided several new pieces of evidence for the glacial abrasion of the late Proterozoic Varangerfjorden unconformity. Additional descriptions of striations and diverse pits and embedded clasts on the unconformity surface at Bigganjargga are given, and it is stressed that the primary glacial features of the unconformity have been destroyed by secondary pits and imprints, most severely just west of the Bigganjargga diamictite, where the intra-Smalfjord hiatus joins the unconformity. This point represents the axial zone of the channel, which eroded the Bigganjargga diamictite and provided a favourable environment for diagenetic and possibly later fluids to attack the unconformity surface. Small grooves visible as positive casts at the base of the Smalfjord Formation are reported from Handelsneset. The general regional features of the unconformity at Vieranjarga and Ruossoai'vi and syn-Smalfjord erosional features at Skjåholmen are described. Roches moutonnées of either late Proterozoic or Pleistocene age that had developed on a Precambrian basement gneiss are reported at Karlebotn. Pleistocene striations and pits on the Veinesbotn quartzite are described for comparison purposes.

Key words: sedimentary rocks, unconformities, glacial erosion, striations, gneisses, roches moutonnées, Proterozoic, Bigganjargga, Handelsneset, Skjåholmen, Smalfjord, Finnmark, Norway

Kauko Laajoki: University of Oulu, Department of Geology, Box 3000, 90401 Oulu, Finland, and Mineralogical-Geological Museum, University of Oslo, Sars' gate 1, 0562 Oslo, Norway.

E-mail: kauko.laajoki@oulu.fi 


\section{INTRODUCTION}

The recent paper of Jensen and Wulff-Pedersen (1996), which once again rejects a glacial origin for the classical striated surface at Bigganjargga, has inspired fruitful discussions and research on this outcrop, which is one of the benchmark localities in Precambrian geology (Edwards 1997, Jensen \& Wulff-Pedersen 1997, Laajoki 1999a, b, 2002, Rice \& Hofmann 2000). A comprehensive historical review of the research carried out to date and opinions expressed regarding the Bigganjargga surface is given in the author's recent paper (Laajoki 2002).

In spite of its classical nature, the Bigganjargga surface has been studied relatively little, and the authors of the "non-glacial school" (Crowell 1964, 1999, Harland 1964, Harland \& Rudwick 1964, Harland et al. 1966, Schermerhorn 1971, 1974, Jensen \& Wulff-Pedersen 1996, 1997, Arnaud \& Eyles 1999) do not take into account that it is part of a significant regional unconformity. This regional connection had already been established by Rosendahl $(1931,1945)$ and was convincingly confirmed later by Bjørlykke (1967) and Edwards (1984). Recent new observations of striations at Handelsneset, Ruossoai'vi and Skjåholmen (Laajoki 1999b, 2002), and the possible striations at Saranjargåp'pi (Fig. 2f in Rice \& Hofmann 2000) confirm that glacial abrasion was a significant agent in the formation of this regional unconformity.

The present paper is aimed at completing author's account of his investigations around Varangerfjorden, laying the main emphasis on some new observations of glacial and destruction features on the Bigganjargga surface. It introduces a few new photographs of Handelsneset, Vieranjarga, Ruossoai'vi and Skjåholmen, and describes interesting gneiss outcrops at Karlebotn, which may represent Precambrian roches moutonnées. Finally, some examples of Pleistocene glacial features visible on the Veinesbotn quartzite at Veinesbotn are described.

For shortness' sake the term unconformity is used in the meaning "surface of unconformity" (Bates \& Jackson 1995). If the clarity of the text requires, expression "unconformity surface" will be applied.

\section{GEOLOGICAL SETTING}

A condensed review with relevant references of the geology of the Varangerfjorden area is given in the author's paper (Laajoki 2002, see also Siedlecka \& Roberts 1996), so that it is enough for the present purpose to say that the late Proterozoic sedimentary rocks in the area concerned were deposited non-conformably on late Archaean and early Proterozoic rocks of the Fennoscandian Shield (Fig. 1). The Varangerfjorden unconformity (VFU) is a low-angle "pre-tillitic" angular unconformity that separates the Vads $\varnothing$ and Tanafjorden Groups from the Vestertana Group, which has two well-known tillite-bearing units: the Smalfjord and Mortensnes Formations (see the lithostratigraphic inset in Fig. 1). In the south, at Vieranjarga, Ruossoai'vi and Bigganjargga, the unconformity dips to the north, whereas at Handelsneset and Skjåholmen it dips to the south. This led Bjørlykke (1967) to conclude that the unconformity represents a glacial palaeovalley, which follows the present Varangerfjorden. The present author accepts this idea, as reflected in the fact that the unconformity is named informally after Varangerfjorden (Laajoki 2002).

\section{AUTHOR'S PREVIOUS OBSERVATIONS}

In order to make it easier for a reader to follow this completing paper a brief summary of author's previous results of the study topic (Laajoki 1999 $a, b, 2002)$ is given below. The study concentrated merely on the unconformity surface, and the disputed origin of the Bigganjargga and other Smalfjord diamictites was not treated and will not be discussed in the present paper.

The regional angular unconformity that separates the late Proterozoic (Riphean-Vendian) Vad$s \emptyset$ and Tanafjorden Groups from the overlying Varangerian (late Vendian) glacigenic rocks (the Smalfjord, Nyborg and Mortensnes Formations) of the Vestertana Group was remapped on both sides of southwestern Varangerfjorden and was studied in detail at Bigganjargga, Handelsneset, Skjåholmen and Vieranjarga (Fig. 1). 


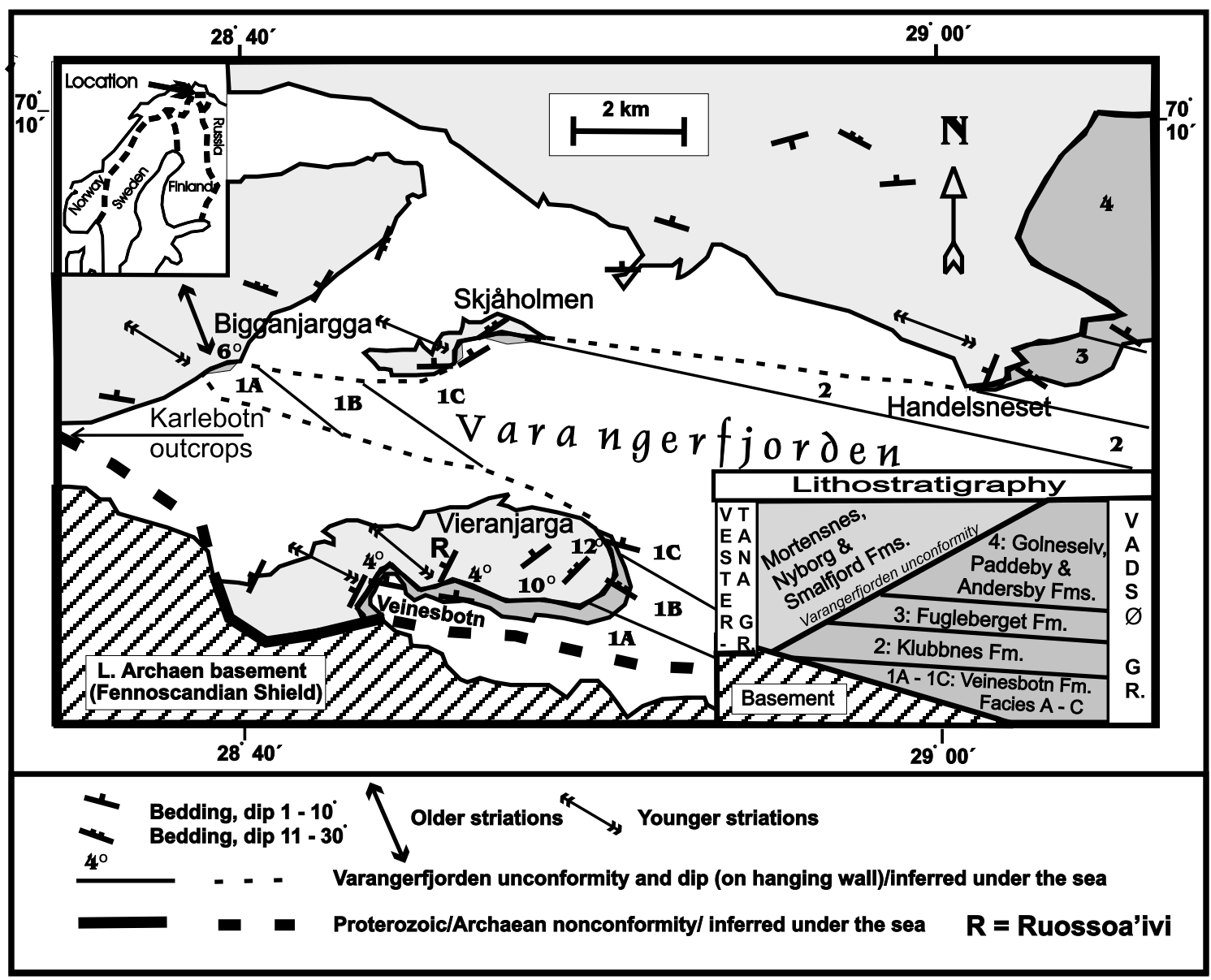

Fig. 1. Geological map of the Varangerfjorden area (modified after Siedlecka 1990, 1991, and Laajoki 2002). For the location and lithography see the insets.

Sedimentological and petrographic studies across the Veinesbotn/Smalfjord contact confirmed that this surface is an angular unconformity. This was not a new result, because this quite an obvious relationship was established already by Rosendahl $(1931,1945)$ and can be seen easily both on the outcrop and in Bjørlykke's (1967) illustrative Fig. 5.

The inferred ice-flow directions of the older and younger striation and small groove (terminology after Laverdière et al. 1985) sets were measured on the classical striated Bigganjargga surface. The results were $325^{\circ}(\mathrm{N}=69)$ and $283^{\circ}(\mathrm{N}=17)$, respectively, and match well with those of Rice and Hofmann (2000). The actual ice-flow directions could not be determined but previous ideas of probable northwesterly and westerly directions were used.

It was detected that the part of the unconformity east of the classical Bigganjargga surface is not a plane but part of a wider striated trough.

The non-glacial, soft-sedimentary origin of the diverse pits and imprints on the Bigganjargga surface was rejected on the basis that the surface was developed on a hard rock. Diagenetic modification of the surface was considered as one possibility and these features are treated in more detail in this paper.

New observations of late Proterozoic glacial striations and small grooves were made at Handelsneset, Skjåholmen and Ruossoai'vi. Their inferred ice-flow directions are closer to that of the 
younger set than that of the older set at Bigganjargga. This and the channelized nature of the eastern part of the Bigganjargga surface were considered to support glacial abrasion of the VFU and to indicate that the Bigganjargga surface is an essential part of this regional feature. This again was not a new observation, because already Rosendahl (1931) correlated the Bigganjargga surface with the unconformity at Handelsneset and Bjørlykke had presented the idea of the Varangerfjorden glacial palaeovalley in 1967.

At palaeotopographically higher parts of $\mathrm{Vi}$ eranjarga, the subglacially abraded unconformity was detected to have been destroyed in part by syn-Smalfjord in situ brecciation attributed to periglacial frost shattering. A large part of the unconformity at East Vieranjarga and Skjåholmen was described to have been incised by intraSmalfjord (interglacial) erosion, which proceeded several metres down to the underlying Vads $\varnothing$ Group basement.

An extensive literature research revealed that there are no features to differentiate late Proterozoic glacial abrasion processes from those of Palaeozoic or later ice ages on the unconformity. It was stressed that special care is needed in distinguishing glacigenic soft-sediment striations and small grooves from those inscribed in hard rock. The former mark the presence of a hiatus or disconformity within a stratigraphic sequence and may be produced subglacially or by floating ice whereas the latter indicate in most cases a marked angular unconformity, of which the Bigganjargga surface is a classical example, or a nonconformity.

\section{THE UNCONFORMITY AT BIGGAN-}

\section{JARGGA}

The VFU at Bigganjargga can be subdivided on the basis of its geometry and secondary features into the following five parts (Fig. 2): (1) the eastern channelized part, detected only recently (Laajoki 2002), (2) the classical striated surface on which other authors' studies have been concentrated, (3) the "pockmarked" surface, which intersects both the unconformity and the underlying Veinesbotn quartzite, (4) the embedding surface, which is joined by (5) the intra-Smalfjord (supra-diamictite) hiatus, and (5a) the composite unconformity/hiatus surface, which is overlain by the Smalfjord turbiditic sandstone in the westernmost part of the outcrop.

The channelized part of the unconformity (Surface 1 in Fig. 2)

The likely reason for previous researchers failing to detect the channelized part of the unconformity is that it occurs within the present intertidal zone and is covered by algae. The author detected it in summer 1998 and obtained permission to clean it carefully in summer 1999, when it was also photographed. As seen in Fig. 3a, the channel, with its eastern margin continuing under the sea, is very shallow and undulating. The axis of the channel seems to be sub-parallel to the average direction $\left(325^{\circ}\right)$ of the inferred older ice-flow direction. It is important to note that the boundary between the channel and the plane-like extension of the classical striated surface is not rounded but angular and abrupt. Apart from a small portion at the westernmost end, only a vertical cross-section of the channelized part can be studied. One cross-section of a ridge (Fig. 3b) was seen in this part, and it was not possible to study to what extent the unconformity is striated. Faint striations were detected only on the small westernmost part close to the classical surface. It is not possible on the basis of these fragmentary observations to say whether the channel was formed by the same glacial abrasion that striated and planed the classical surface or before this.

The classical striated surface (Surface 2 in Fig. 2)

The eastern part of the classical surface (Fig. 4 in Rosendahl 1945, Fig. 5b in Laajoki 2002) and the part between it and the channelized part (Fig. 3c) are fairly well preserved. The diverse pits and imprints that are abundant west of the classical surface (see below) are rare here. Rice and Hofmann (2000) argue that Precambrian polish has 
been preserved on the seaward edge of the classical surface, but Laajoki (2002) interprets this feature as a reaction surface. It is significant that the margins of the striations in Fig. 2d of Rice and Hofmann (2000) are not straight (cf. Fig. 3c) but rugged or "etched", and that even the rugged parts are "polished". Furthermore, the bottoms of the striations are flatter than is typical of well-preserved striations in other parts of the surface, and no internal hair-line striation typical of well-preserved younger striations and small grooves (Fig. 9a in Laajoki 2002) can be seen. On the northern part of the surface, however, under the protecting shelter of the overlying diamictite, there is a thin relic of polished area preserved on a striation of the older set (Fig. 3d). In this case the striation is not covered by a glassy quartz film, but instead the coating appears to represent sheared rock material from its pavement. This indicates that the film may represent primary Precambrian polish.

The diverse pits and imprints on the classical surface have been discussed recently by Jensen and Wulff-Pedersen (1996) and by Rice and Hofmann (2000), the former considering them softsedimentary features (for opposite opinions, see Edwards 1997 and Laajoki 2002). The latter authors connected many of the imprints with late Proterozoic (syn-Smalfjord) glacial erosion of a possible Veinesbotn mud flake conglomerate by a tillite, but this hypothesis seems to be rather speculative, as no evidence of the supposed mud flakes can be seen in the Veinesbotn Formation at Bigganjargga. The fact that mud flakes or their holes have been encountered at Vieranjarga is of no value as strict scientific proof.

A close-up of the asymmetric imprints with a deeper northwestern part, used by Jensen and Wulff-Pedersen (1996) as evidence that the depressions represent imprints of clasts contained in the overlying diamictite, is depicted in Fig. 3e. Since the surface has been modified by recent erosion, as shown by the nearby striations, it is not possible to explain this structure with any confidence. It is important, however, to note that the foreset lamination of the troughs of the cross-bedded Veinesbotn quartzite are preserved perfectly both on the unconformity surface and within the depressions. This argues against the statement that the surface had been somewhat soft or non-consolidated when the striations were formed. The tiny mineral and rock grains on the surface may represent clasts distributed within the Veinesbotn quartzite (cf. Fig. 4d), not clasts embedded from the overlying diamictite. A close-up of Fig. 9 of Jensen and Wulff-Pedersen (1996), which they used as evidence that the striations are directly related to diamictite deposition, shows that the imprint close to the end of the striation is very obscure and cannot be said to be directly connected with the striation (Fig. 3f). The same figure also shows a flat-bottomed imprint about $4-5 \mathrm{~cm}$ in diameter but only $2-5 \mathrm{~mm}$ deep. If this pit was caused by a clast, the clast would have had to be tabular in form, but no fragments of this kind are present in the overlying diamictite. A close-up of the clast attached to the pavement in Fig. 7 of Jensen and Wulff-Pedersen (1996) is provided in Fig. $3 \mathrm{~g}$. On the basis of its glassy appearance, the pavement/clast boundary and the embedding of the clast must be attributed to pressure solution. The figure also demonstrates destruction of the striations by comparison with those in Fig. 3c.

\section{The "pockmarked" surface (Surface 3 in Fig. 2)}

The fact that the classical striated surface was gradually destroyed by flat-bottomed, irregular pits located side-by-side in its western part is stressed by Laajoki (2002, Figs. 9c-d), who also demonstrated that this surface leaves the unconformity and continues as a shallowly dipping surface within the Veinesbotn quartzite intersecting several cross-bed sets (Figs. 4a-b). In order to separate this throughout pitted surface from the parts of the VFU pitted with fewer and deeper pits (e.g. Fig. 4f) it is called the "pockmarked" surface.

The close-up of this surface within the Veinesbotn quartzite shown in Fig. $4 \mathrm{c}$ demonstrates that the pits are of diverse forms. Some of them are so sharply bounded at their margins that they could be interpreted as erosional holes of weathered-out mud fragments, but most of them are so irregular that this interpretation is excluded. Al- 
though there are several hundred pits on the surface, none of them was found to contain any traces of the speculative mudstone or siltstone fragments. This together with the crosscutting nature of the surface indicates that the pits are solution features. A close-up of another surface within the Veinesbotn quartzite (Fig. 4d) shows quartz, microcline and granite granules, some of which have been leached out.

The embedding part of the unconformity (Surface 4 in Fig. 2)

An important part of the unconformity is its continuation west of the "pockmarked" site (Fig. 4a). Here the surface contains abundant clasts embedded in the Veinesbotn quartzite (Fig. 4e), or else the unconformity is corroded by diverse pits (Fig. 4f). In order to separate this part from the areas with solitary pits and clasts (e.g. Fig. 3e) it is named the embedding part of the unconformity. Striations are visible only locally on it (Fig. 4f). The embedded clasts are of granule to pebble size and include distinctive dark siltstone and red sandstone, which are derived from facies $\mathrm{C}$ of the upper part of the Veinesbotn Formation (Hobday 1974). The clasts differ in amount and composition from those of the Bigganjargga diamictite, but are similar to the conglomeratic parts of the turbiditic Smalfjord sandstone, which most likely were resting directly on this part of the unconformity at one time (Fig. 4a and the next section). Most of the clasts and pits are surrounded by thin, white quartz-rich seams, which are interpreted as reaction seams. The margin geometries of the embedded clasts and the pits are so similar (Figs. 4e and 4f) that at least some of the latter may represent weathering holes of the former. All the clasts and their probable weathering holes give the impression that the clasts were pressed vertically into the pavement.

The westernmost part of the unconformity (Surface 5 a in Fig. 2)

West of the embedding part, the unconformity is covered by loose blocks and slabs deriving from the overlying Smalfjord sandstone (Fig. 4a). A small part cleared of the loose material revealed that the unconformity is striated here as well but does not seem to contain any significant amounts of imprints or embedded clasts (Fig. 4g). Some pits occur, but these seem to be of recent origin resulting from pressure of the overlying sandstone blocks. The unconformity is overlain first by a thin conglomeratic layer (ca. $10 \mathrm{~cm}$ ), which may represent winnowed diamictite material. Then follows a series of thin turbidite beds, many of which have pebbly lower parts. The pebbly part in Fig. $4 \mathrm{~h}$ resembles the embedding part in Fig. 4e in both its pebble composition and texture. This indicates that the clasts on the latter surface (Fig. 4e) represent embedded clasts of pebbly Smalfjord sandstone.

Intra-Smalfjord hiatus surface (Surface 5 in Fig. 2)

The presence of striations and small grooves on the embedding surface and its western extension (Figs. 4f and 4g) and the winnowed upper part of the Bigganjargga diamictite (Edwards 1975, 1984) indicate that there was a significant period of erosion after the deposition of the diamictite. West of the present relict diamictite lense, this erosion removed all diamictite material so that a thin layer of winnowed diamictite material and turbiditic Smalfjord sandstone could deposit directly on the exposed striated unconformity. The surface produced by this erosion is named the intra-Smalfjord hiatus. It drapes the diamictite and joins the unconformity west of it (Fig. 2).

Progressive development of the Varangerfjorden unconformity at Bigganjargga.

On the basis of the observations described above and the author's previous paper (Laajoki 2002), the development of the VFU at Bigganjargga can be divided into the following stages:

(0) Pre-glacial (pre-Smalfjord) tilting and erosion of the underlying sequence (Vads $\varnothing$ and Tanafjorden Groups) and formation of the VFU.

(1) Probable glacial erosion of the eastern channelized part of the unconformity, and

(2) glacial striation and grooving of the uncon- 


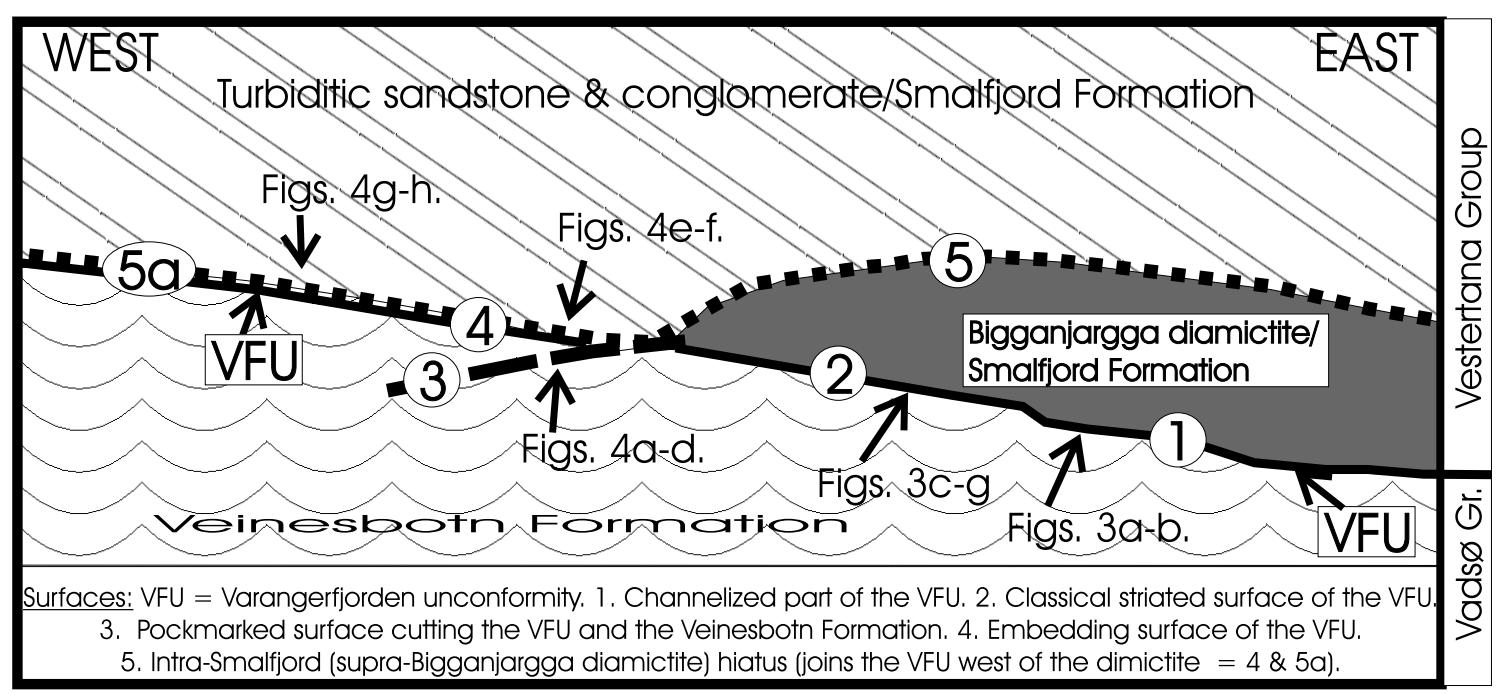

Fig. 2. Schematic cross-section of the Bigganjargga outcrop. The various surfaces and the locations of the photographs are indicated. Not to scale. The approximate width of the cross-section is $20 \mathrm{~m}$.

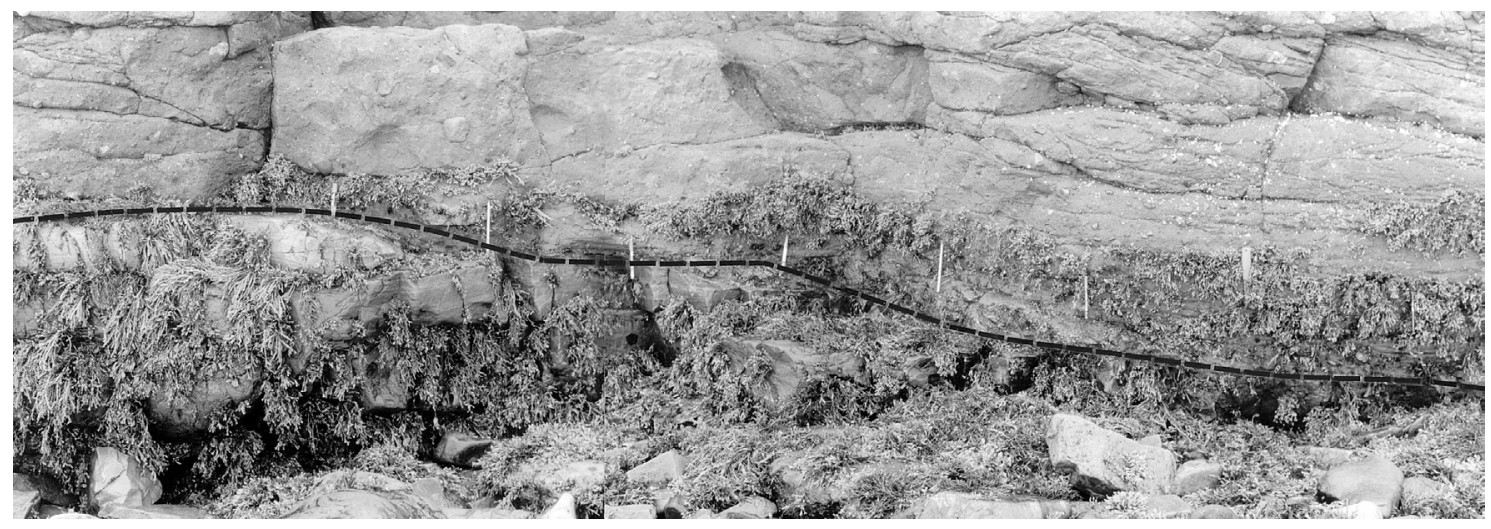

Fig. 3. The Varangerfjorden unconformity under diamictite at Bigganjargga. Photos K. Laajoki. (A) View of the channelized part, about $3.5 \mathrm{~m}$ wide (dashed line), under the diamictite. The plane-like extension of the classical surface is visible left of the leftmost marker. The part was cleaned for the photograph in summer 1999. Photo Va9-15. (Continues on pp. 24-25)

formity surface. It is an open question whether events 1 and 2 were exactly simultaneous.

(3) Deposition of the diamictite. If the overlying deposit really is a debris flow, the glacial erosion of the unconformity and the deposition of the diamictite were two separate events.

(4) Subaquatic or subaerial erosion, winnowing of the diamictite and formation of the intra-Smalfjord hiatus.

(5) Deposition of the winnowed diamictic material and turbiditic Smalfjord sandstone on the newly exposed unconformity.

(6) Burial of the unconformity and its diagenetic to low-grade metamorphic modification during the Caledonian orogeny. Embedding of the clasts into the Veinesbotn quartzite and formation of diverse pits and imprints on the unconformity and on the "pockmarked" surface.

(7) Exhumation of the unconformity to the present level of erosion and its modification by Holocene erosion, including attacks by salty seawater and tidal and wave processes. The lack of 

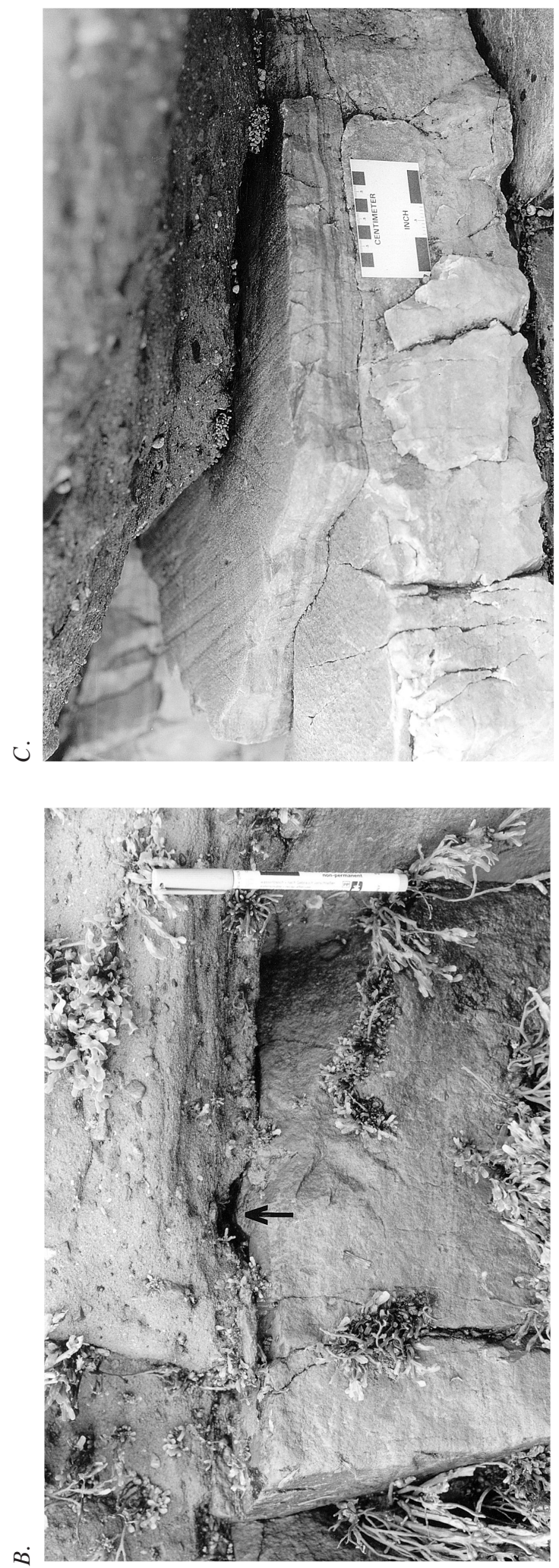
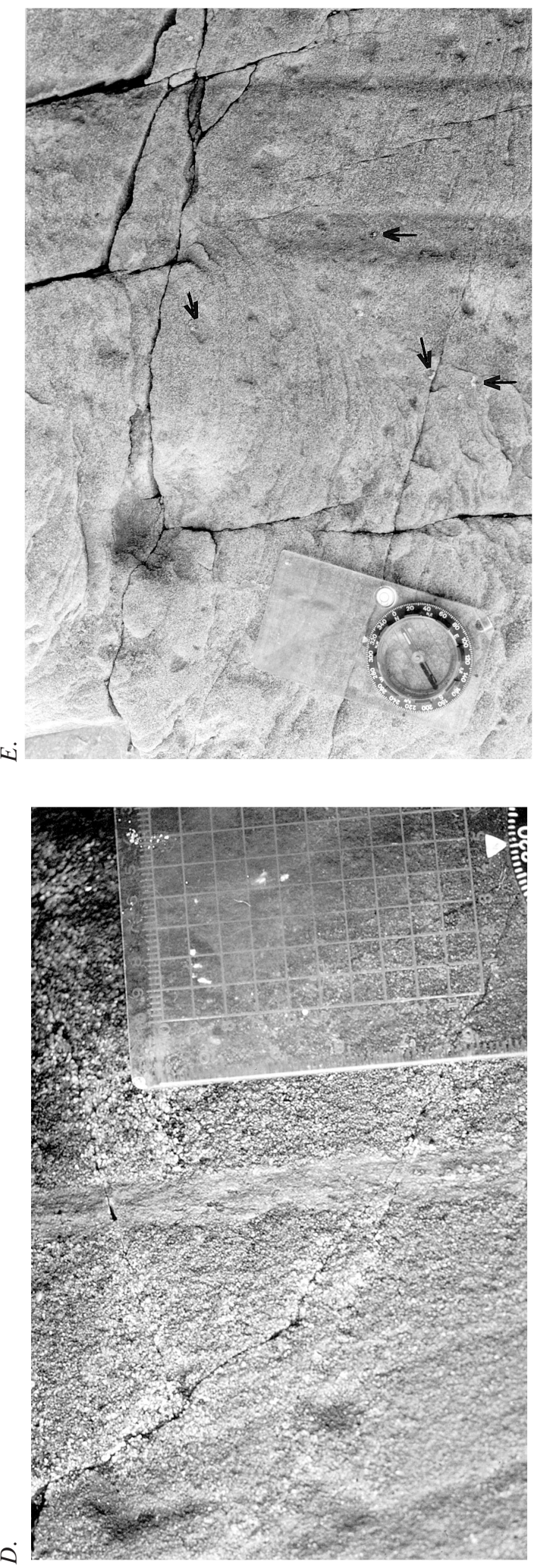


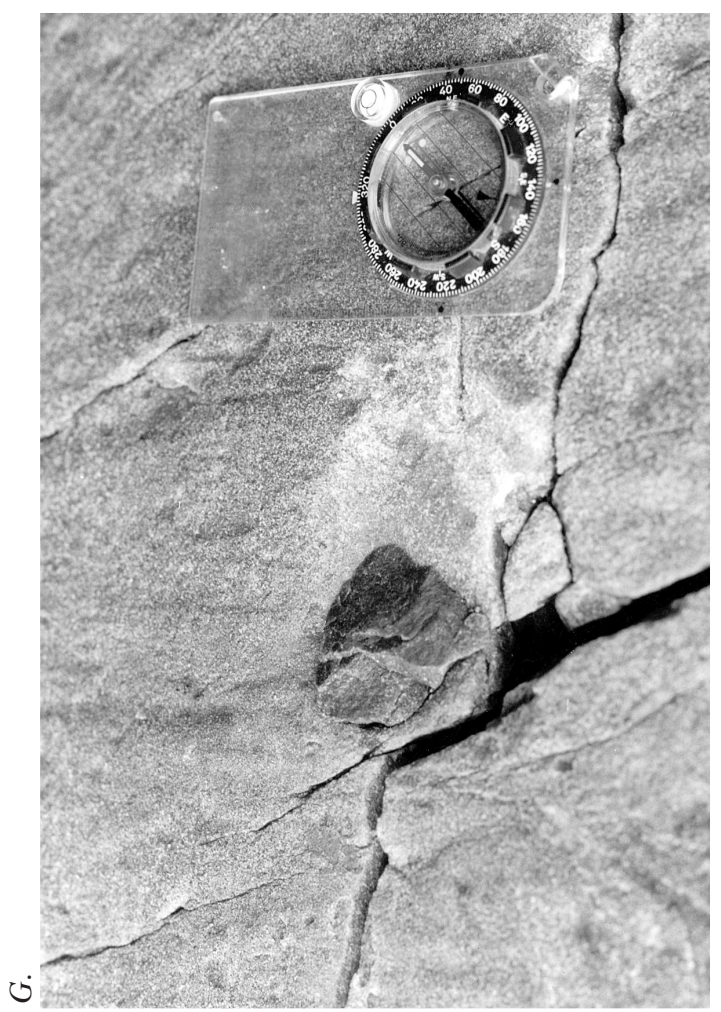

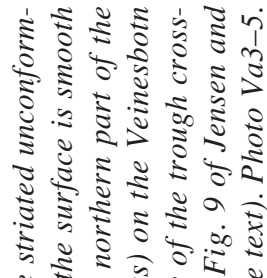

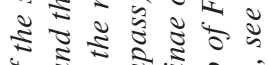

․ 2 .

इड०

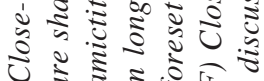

บิ

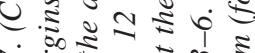

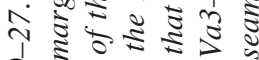

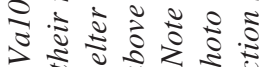

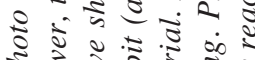

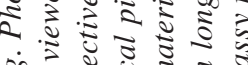

के० 00.5

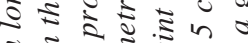

ป

$\forall \bar{y}=\overline{2}=3$

$\therefore$ ₹

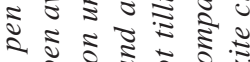

ริ)

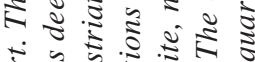

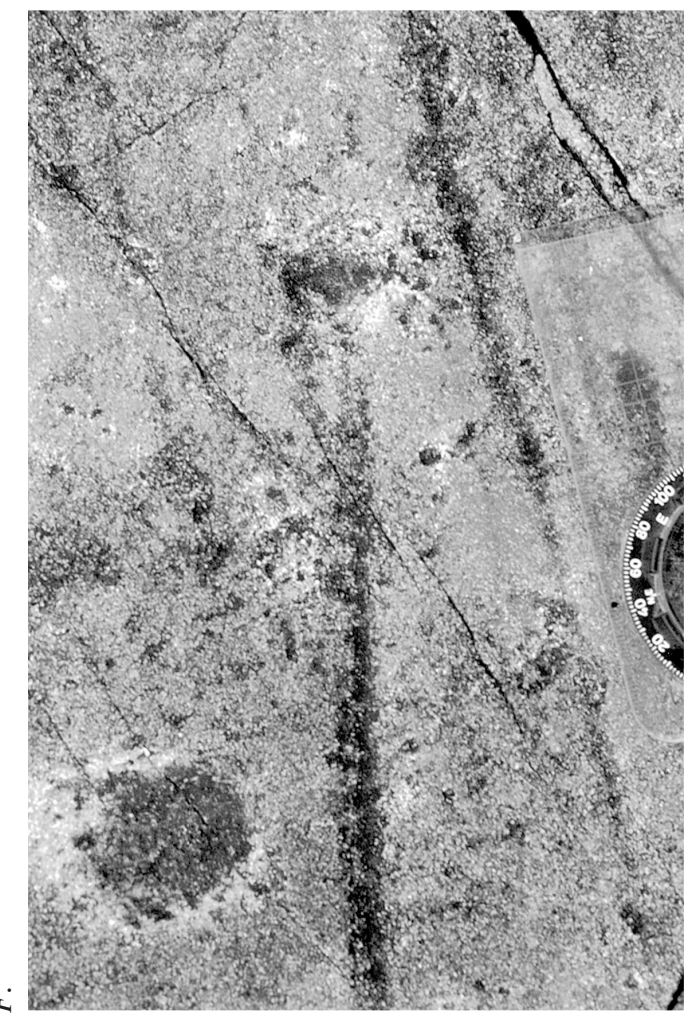

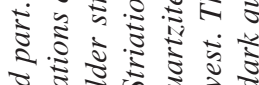

告.

₹

ฐई $5 \infty .5$

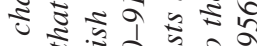

₹ 2000

ะ

วิ

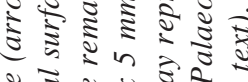

\&.

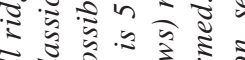

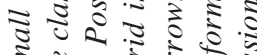

ริธิ์

ชั

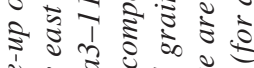

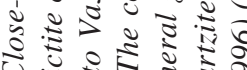

U.

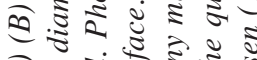

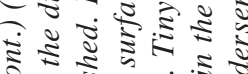

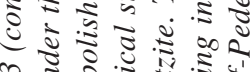

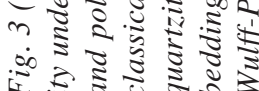



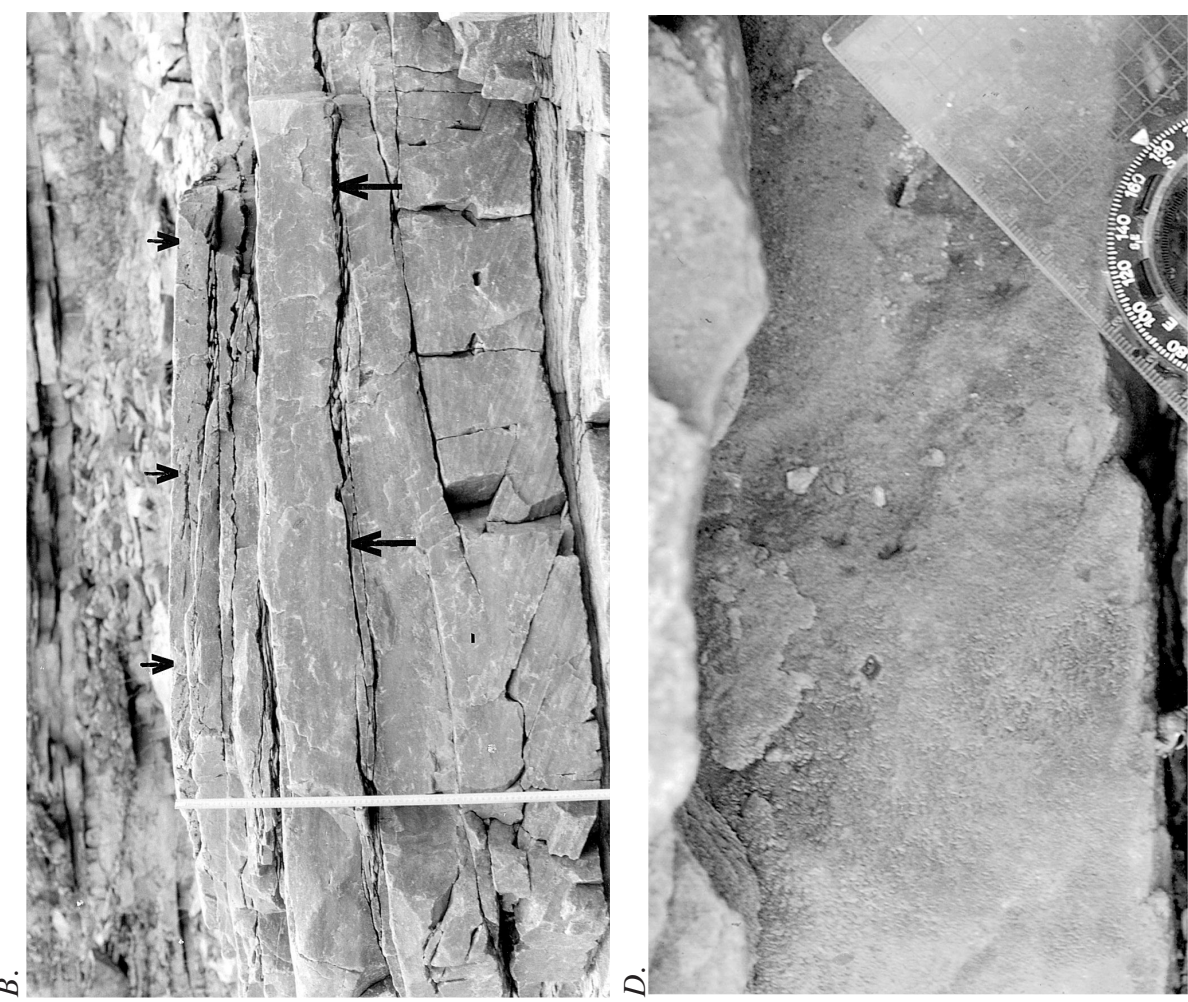

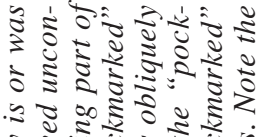

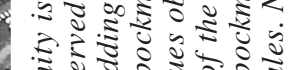

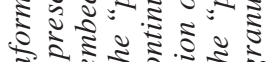
竎.

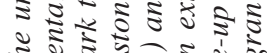
ฐ छ

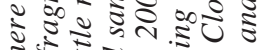
3. ช 050.5

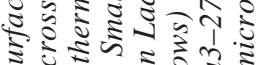
क 8 - 0.0 .50

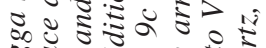

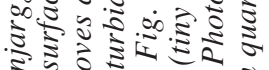

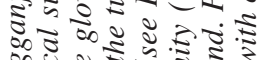

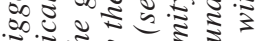

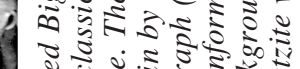

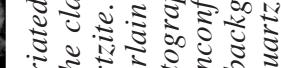

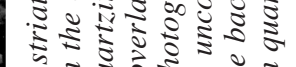
ये

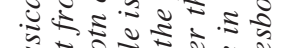

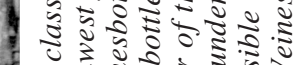

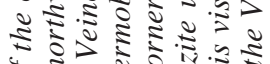
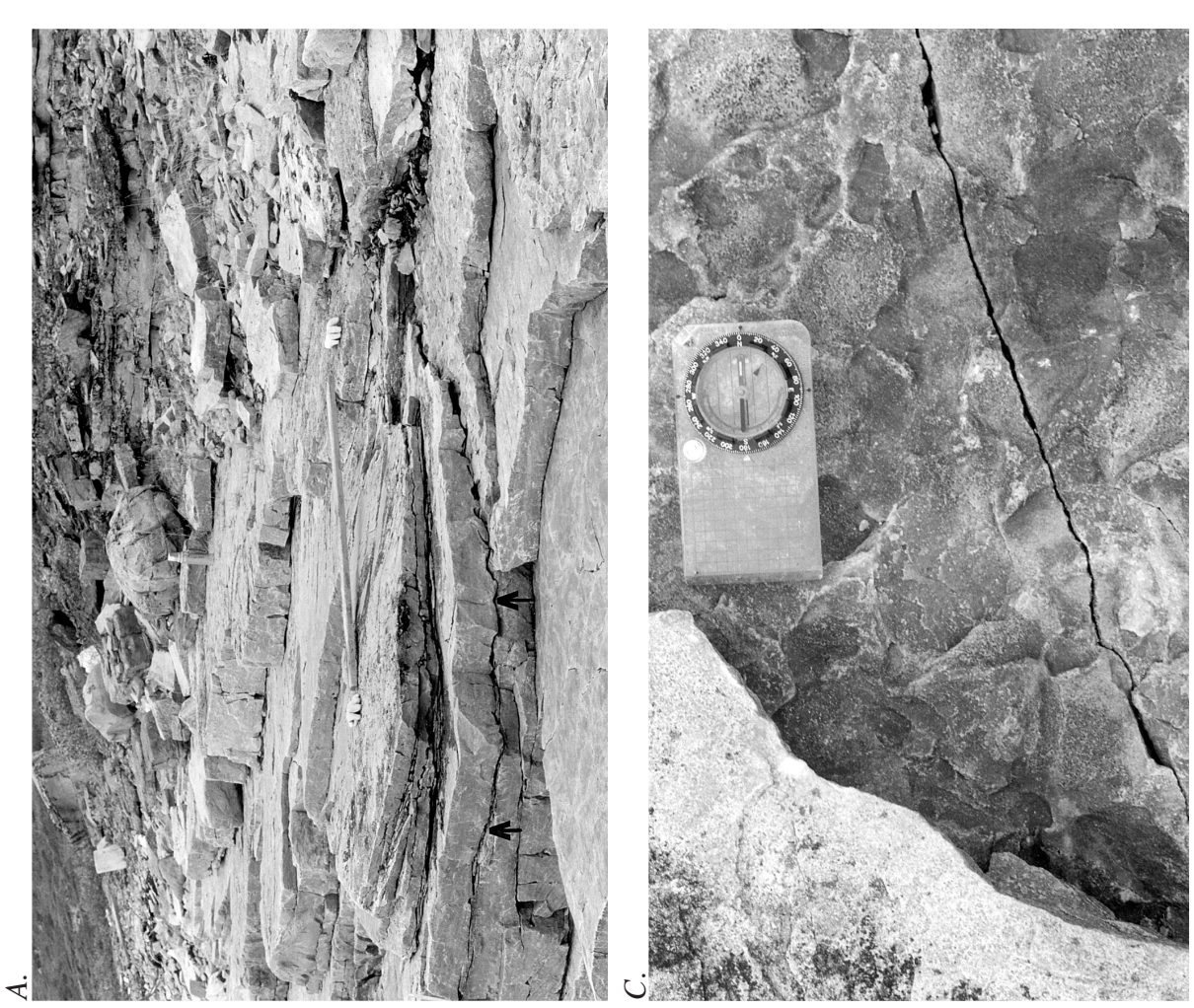
我

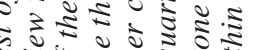

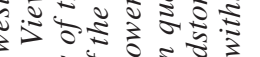
5.

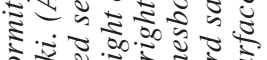

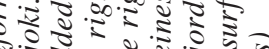

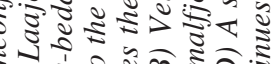

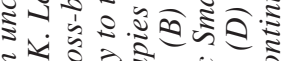

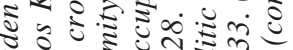
ล5.

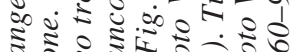

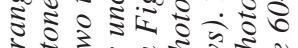

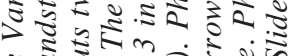
章

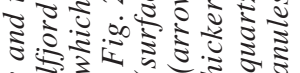
ช

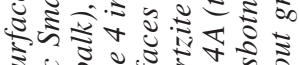

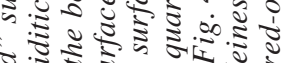

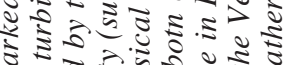

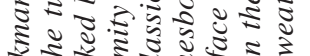

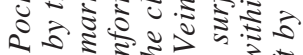

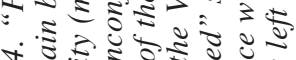
$\pi-3.50 \overline{3}$

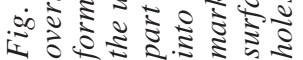



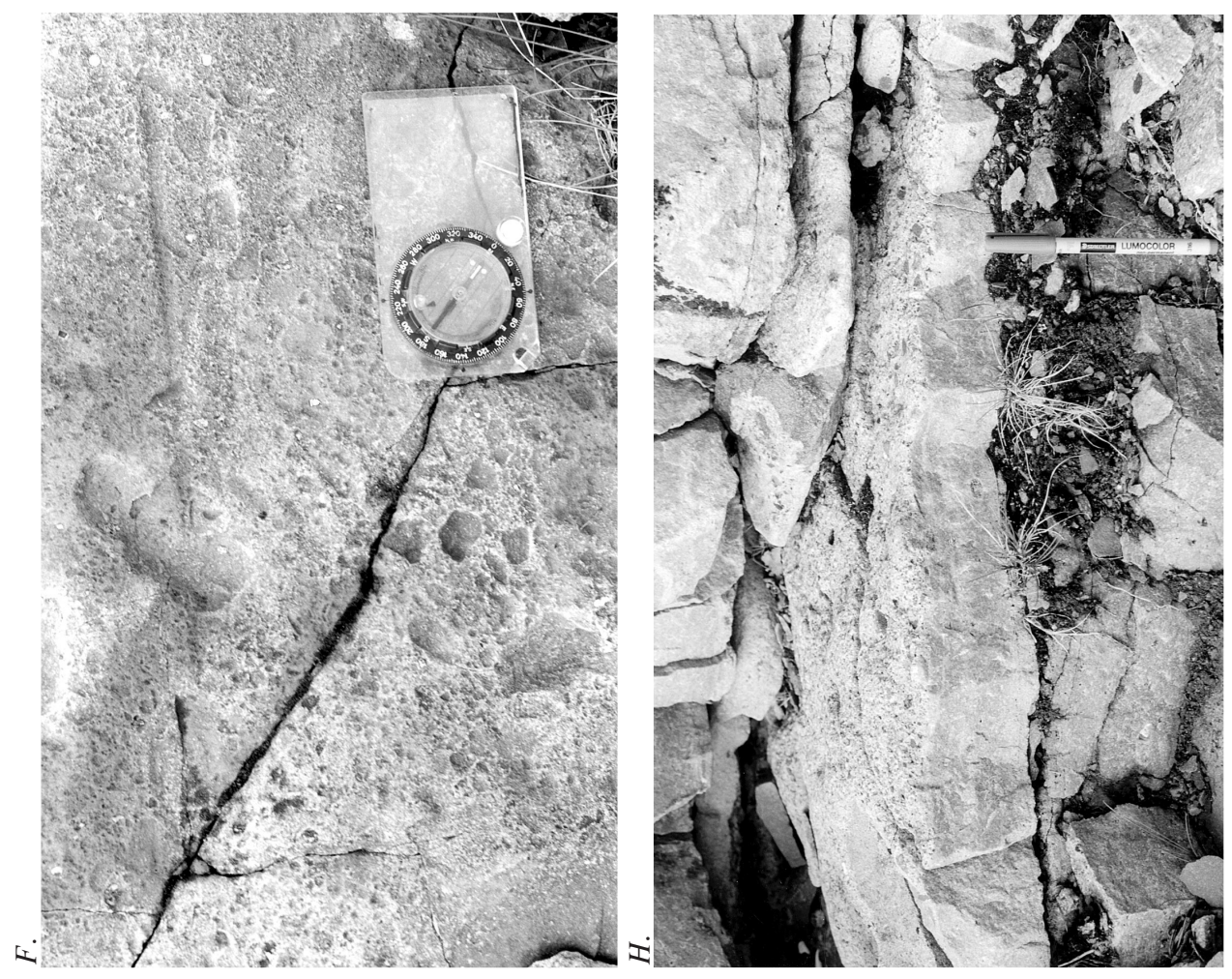

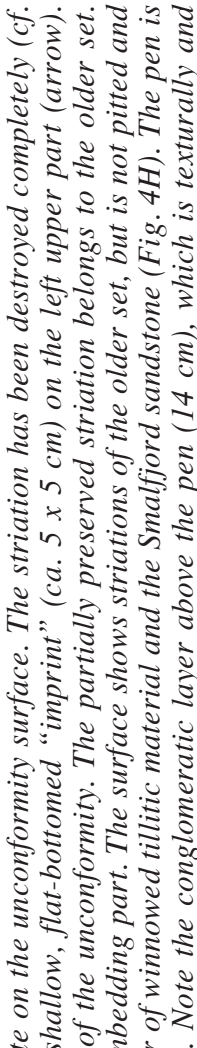
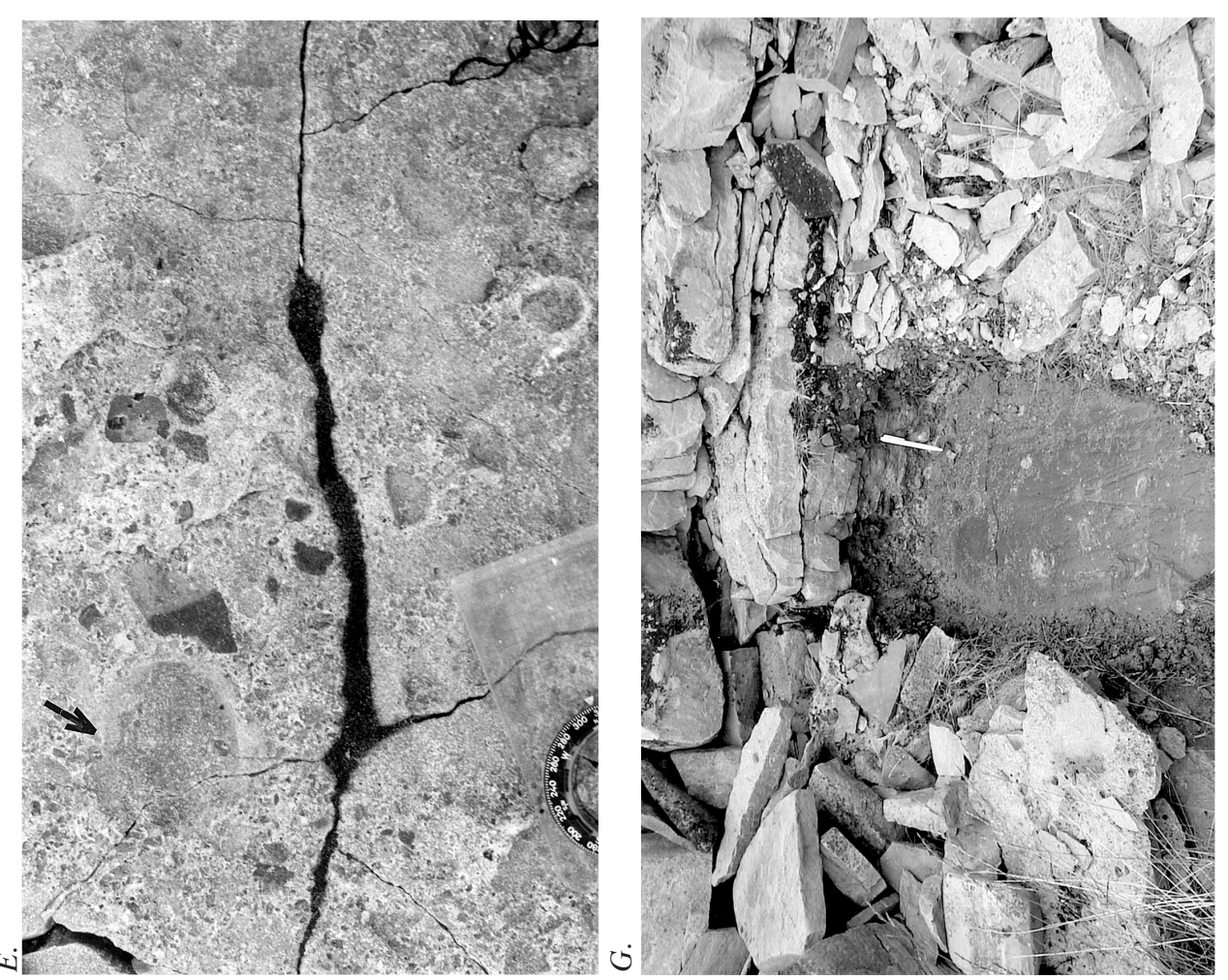

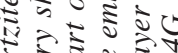

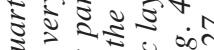

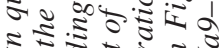
2. จ 5 ปี

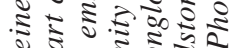

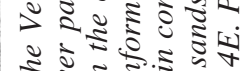

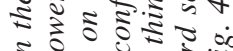

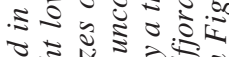

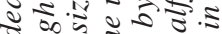

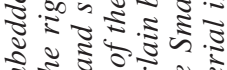

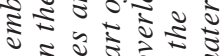

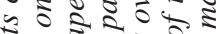

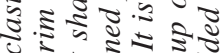

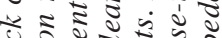

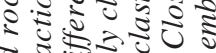

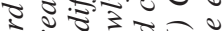
ㄱำ

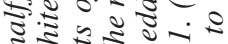

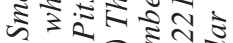

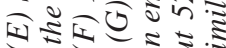

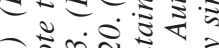

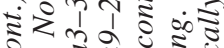

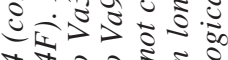

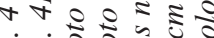

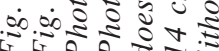


Pleistocene striations on the unconformity indicates that the unconformity visible nowadays at Bigganjargga was exposed from under the Smalfjord Formation fairly recently. It is possible, of course, that they were never formed, or that they were destroyed by recent coastal erosion.

One important open question concerns when and by what process the embedded clasts in Fig. $4 \mathrm{e}$ were planed to their present smooth level.

\section{THE UNCONFORMITY AT VEINESBOTN AND RUOSSOAIVI}

The VFU is visible as a slightly dipping, planar surface for a long distance from the head of the bay of Veinesbotn to Ruossoai'vi (Fig. 5a). Bjørlykke (1967) described striations somewhere close to the head of the bay, and the unconformity at Ruossoai'vi was excavated by the author (Laajoki 2002). A great part of the unconformity is clearcut (Fig. 5b), and it is overlain by Smalfjord conglomerates and sandstones, although a thin seam, probably of tillite, is preserved locally beneath a cobbly turbiditic sandstone (Fig. 5c). Part of the unconformity surface has been destroyed by synSmalfjord in situ brecciation attributed to periglacial frost shattering (op cit.). A wedge of Smalfjord material intruding into the Veinesbotn sandstone along a probably periglacial fracture is depicted in Fig. 5d.

Some 300 m southeast of Ruossoai'vi the unconformity forms a channel at least $100 \mathrm{~m}$ wide and 2-3 $\mathrm{m}$ deep that is filled with Smalfjord diamictites and conglomerates (Fig. 5e).

\section{SMALL GROOVES AT HANDELSNESET}

Glacial striations and small grooves at the eastern part of the classical Handelsneset outcrop (Edwards 1984) were detected only recently (Laajoki 1999b, 2002). At the southern margin of the outcrop area the underlying Fugleberget sandstone has been cleaved away, but the overlying Smalfjord Formation has been preserved in the form of "eaves".
These places give a unique opportunity to observe casts of the unconformity surface from below at the base of the Smalfjord Formation. The cast surface shown in Fig. 5f contains several positive grooves (casts of ridges) up to $1.5 \mathrm{~m}$ long parallel with each other and plunging a few degrees in the direction $290^{\circ}$, i.e. close to that of the striations and small grooves observed in previously published photographs (Figs. 7a-b in Laajoki 2002), and thus supporting the glacial origin of the ridges and small grooves. These observations indicate that the glacially formed VFU has been preserved relatively well at Handelsneset as compared with Skjåholmen. This may be explained by the fact that the unconformity at Handelsneset represents a palaeotopographically higher part of the Varangerfjorden glacial valley than on Skjåholmen.

\section{THE UNCONFORMITY AT SKJÅHOLMEN}

The destruction of the unconformity by post-striation erosion at Skjåholmen has been documented well by Edwards (1984) and Laajoki (2002). This phenomenon is best visible at the southernmost part of the unconformity, within or slightly above the present intertidal zone. In terms of the palaeotopography, this part seems to represent the deepest or axial part of the exposed Varangerfjorden glacial valley. Evidence of glacial abrasion and deposits has been almost completely wiped away, the only known example being the probable tillite lens on the weakly striated unconformity (Fig. 5e in Laajoki 2002). Fig. 5g illustrates another case in which a tiny relic of a probable tillite has been preserved in a threshold pocket of the unconformity. The fragment tail of the Veinesbotn quartzite within the Smalfjord turbidite close to the Veinesbotn/Smalfjord contact in Fig. $5 \mathrm{~h}$ demonstrates undeniably the syn-Smalfjord (poststriation) fragmentation of the VFU. 


\section{POSSIBLE LATE PROTEROZOIC GNEISS ROCHES MOUTONNÉES AT KARLEBOTN}

The Precambrian basement of the Vestertana Group is exposed at Karlebotn (just beyond the western margin of the map in Fig. 1). The outcrops occur within the present intertidal-supratidal zone and are overlain by the Karlebotn quartzite of the Smalfjord Formation. The nonconformity is not exposed, but is covered by Pleistocene and recent deposits.

The westernmost outcrop has features that resemble roches moutonnées. It is elongated in a $\mathrm{N}$ $\mathrm{S}$ direction and is asymmetrical, with a smooth northern (? stoss) side and a rugged southern (? lee) side (Fig. 6a). Striations and small grooves running oblique to the long axis of the outcrop occur on both sides of it (Fig. 6b). Their average trend is $120^{\circ}(\mathrm{N}=20)$, which is close both to that of the Pleistocene striations on the Smalfjord sandstone at Nesseby $\left(112^{\circ}, \mathrm{N}=51\right.$, the direction of ice flow) and the younger, late Precambrian striations at Bigganjargga (c. $105^{\circ}$ if the easterly reading is applied, Rice and Hofmann 2000, Laajoki 2002). As the direction of ice flow cannot be determined at Karlebotn or at Bigganjargga, the age of the striations on the gneiss outcrop at Karlebotn is unknown. They are relatively faint, however, and intersect the smooth hinge of the outcrop so obliquely that they were probably formed after the main abrasion, which would have given the outcrop its roche moutonnée appearance. No striations parallel to the long axis of the outcrop were seen, which seems to cast doubt on the roche moutonnée origin of the outcrop. However, the basement "monadnocks" of Bjørlykke (1967, Fig. 13; cf. Holtedahl 1918, p. 168) at and north of Karlebotn form a N-S trending belt, as is shown on the recent map published by Siedlecka (1990). This indicates that the N-S direction is an important factor in the sub-Smalfjord grain, and that the $\mathrm{N}-\mathrm{S}$ elongation of the Karlebotn outcrop may well be of late Precambrian inheritance.

The asymmetrical form of the gneiss outcrop indicates that the ice that may have formed it flowed from the present north. If this is true, the Pleistocene glaciation is excluded, because it advanced into the area from either the south or south- west and followed the east-west grain of the Varangerfjorden terrain (Nordkalott Project 1986). On the other hand, it has been generally accepted that the Smalfjord glaciation that gave rise to the older set of striations at Bigganjargga advanced to the north. There are no reliable ice-flow indicators at Bigganjargga or at any other place where the VFU is known to be exposed. However, on the basis of a regional palaeogeographic analysis, Edwards (1984, Fig. 80) postulated that several times during phase 2 of the Smalfjord Formation, large ice sheets advanced from the north.

Some 200 m east of the outcrop described above there is another smoothly abraded basement gneiss outcrop, only the southern part of which is exposed (Fig. 6c). This contains striations, which are almost parallel to those on the western outcrop $\left(127^{\circ}, \mathrm{N}\right.$ $=4)$, but lie almost perpendicular to its long axis. If the Precambrian origin of the first roche moutonnée is accepted, this outcrop could represent the lee side of another Precambrian roche moutonnée, again abraded by a Pleistocene glacier.

\section{PLEISTOCENE GLACIALLY ABRADED SURFACES ON THE VEINESBOTN QUARTZITE}

Laajoki (2002, Fig. 7e) reports Pleistocene striations that have developed on the Veinesbotn quartzite (this surface is a western extension of the VFU, as seen in Fig. 5e). Another example of Pleistocene striations developed on the Veinesbotn Formation is depicted in Fig. 6d. In this case the surface does not represent the VFU, but a deeper Pleistocene erosion level exposed in the present intertidal zone. It depicts crescentic fractures, which indicate ice flow in a $64^{\circ}$ direction. This is the only locality where crescentic fractures of this age have been observed on the Veinesbotn quartzite, although Pleistocene striations are fairly common on it at Vieranjarga. Fig. 6e shows secondary pits of unknown origin on the same surface, the occurrence of which indicates that at least some of the pits at Bigganjargga could also be Holocene - recent. 

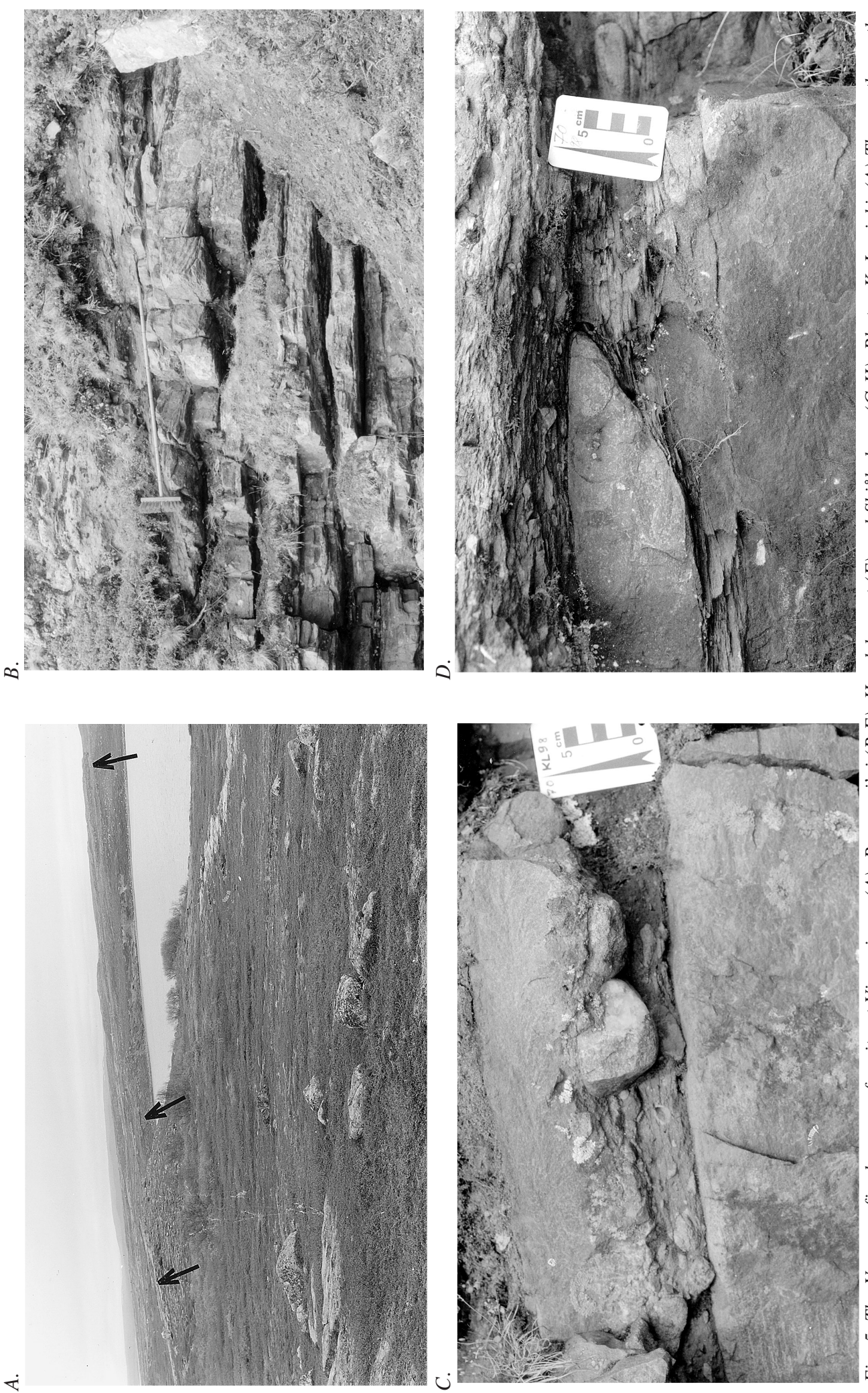

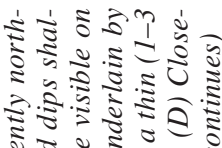
$\therefore$

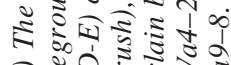
这造专

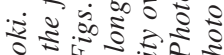
要: $\equiv$

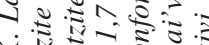

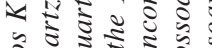

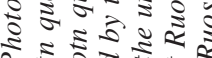

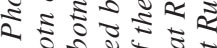

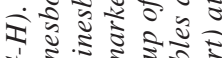

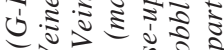

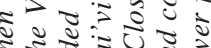
₹

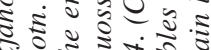

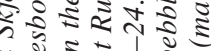

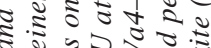

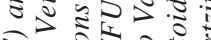

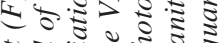

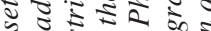
₹ ₹ के के

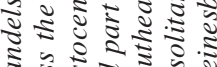

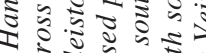

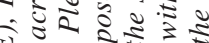

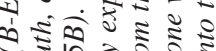

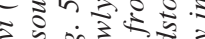
$\Xi \approx$

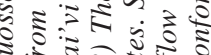

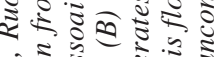
远 $2 x^{2}+1$ is

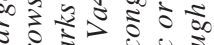
है 品

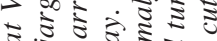
है क⿺辶一

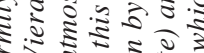
色造,

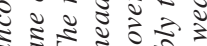

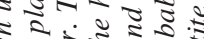

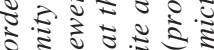
每 is

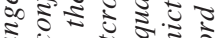
亏

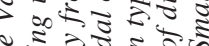

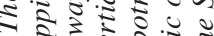

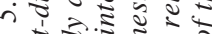
क力 

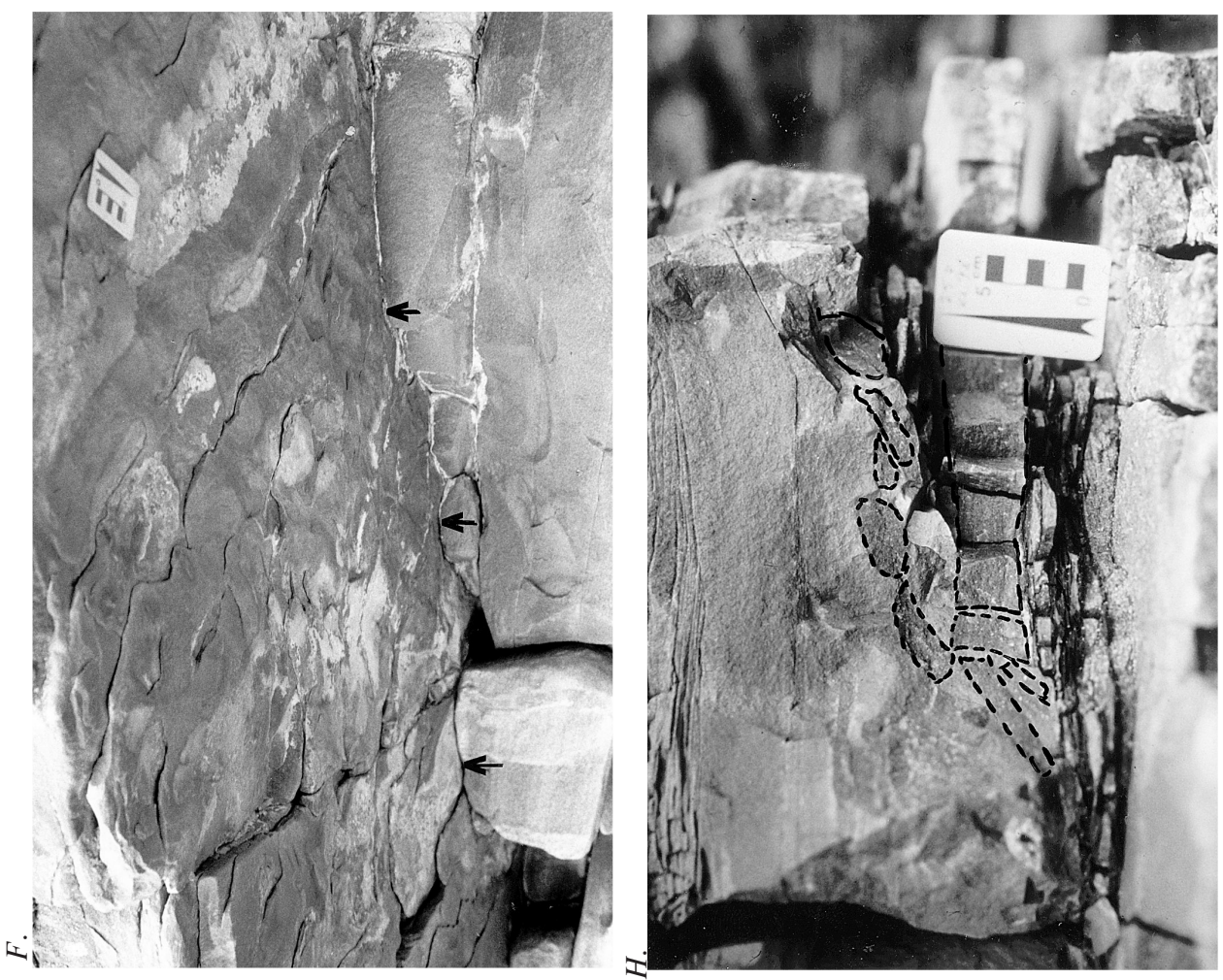

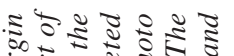

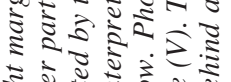

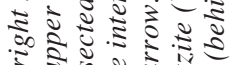

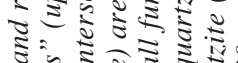

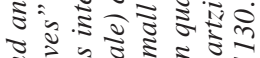

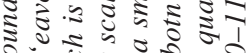

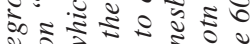

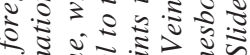

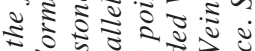

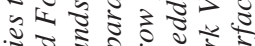

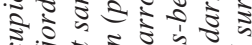

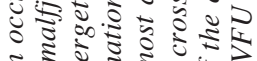

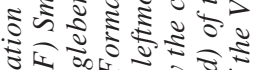

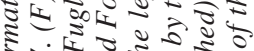

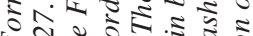

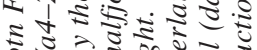

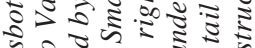

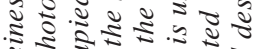

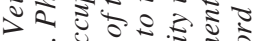
₹

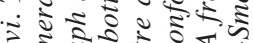

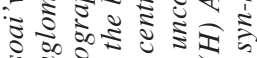
ใับ

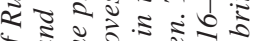

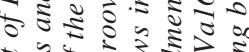
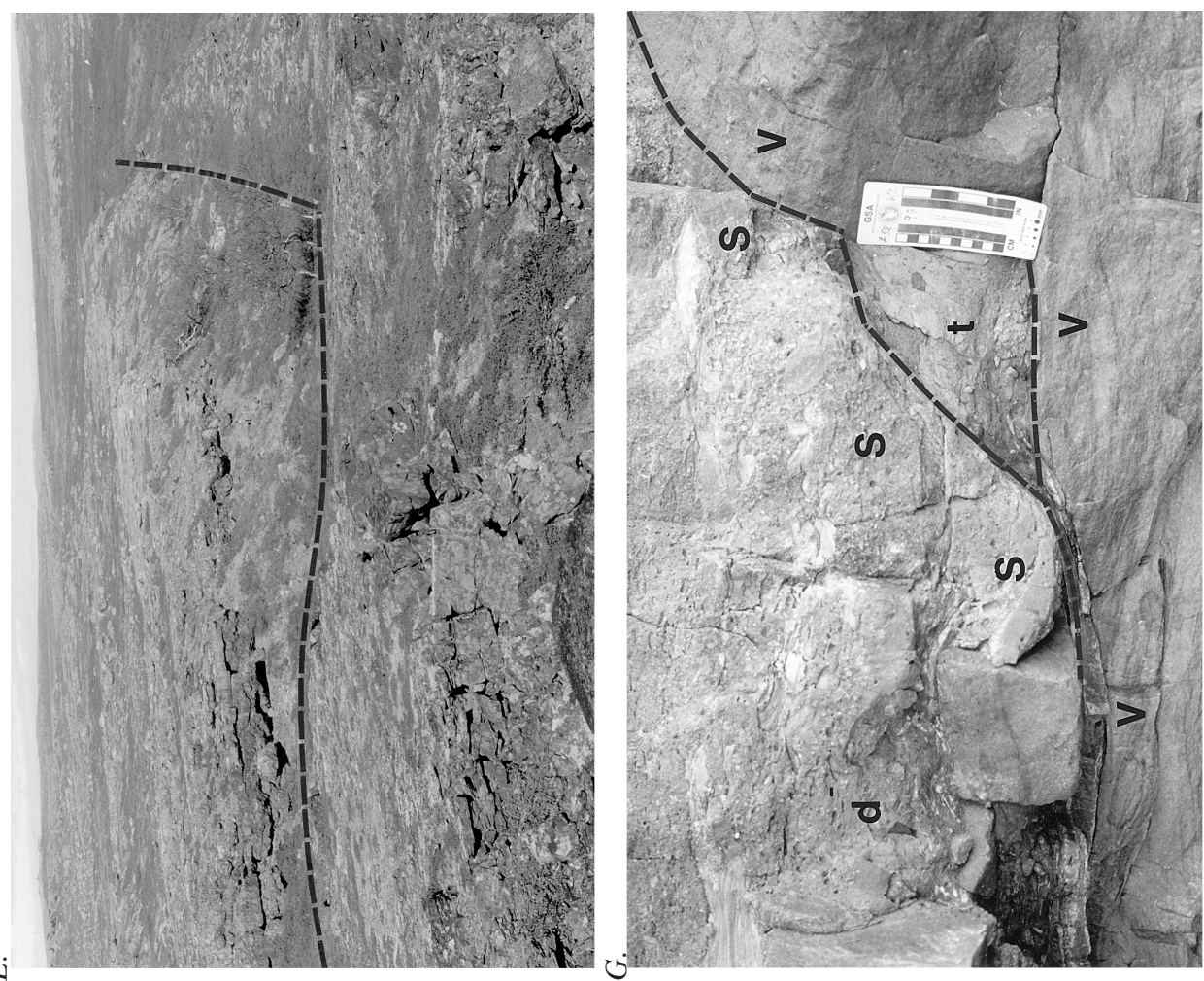

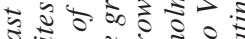

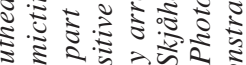
व. क्ष

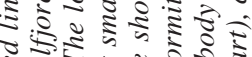
ะ)

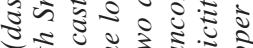

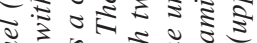

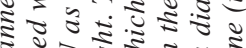

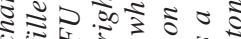
ठ

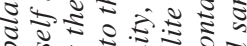

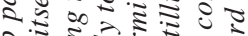
ชัส

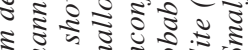
इ क ज 记

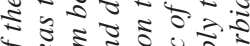

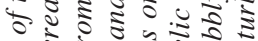

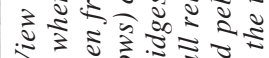
उ.

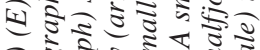
过

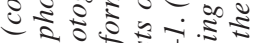

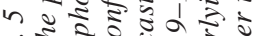
so 
A.

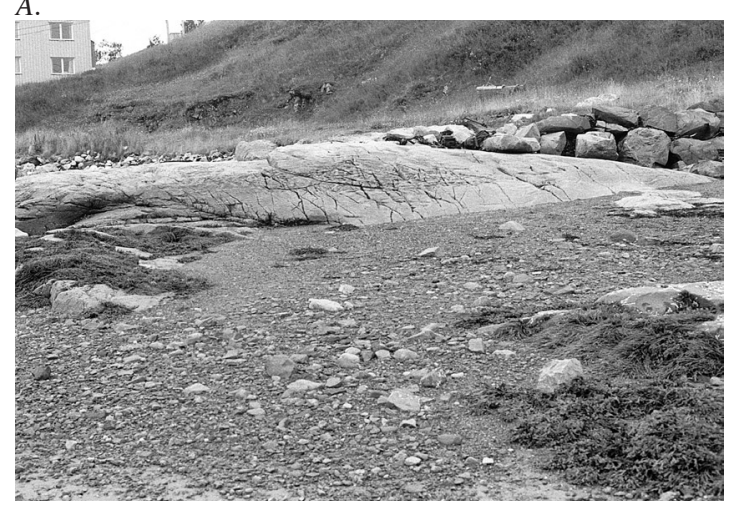

C.
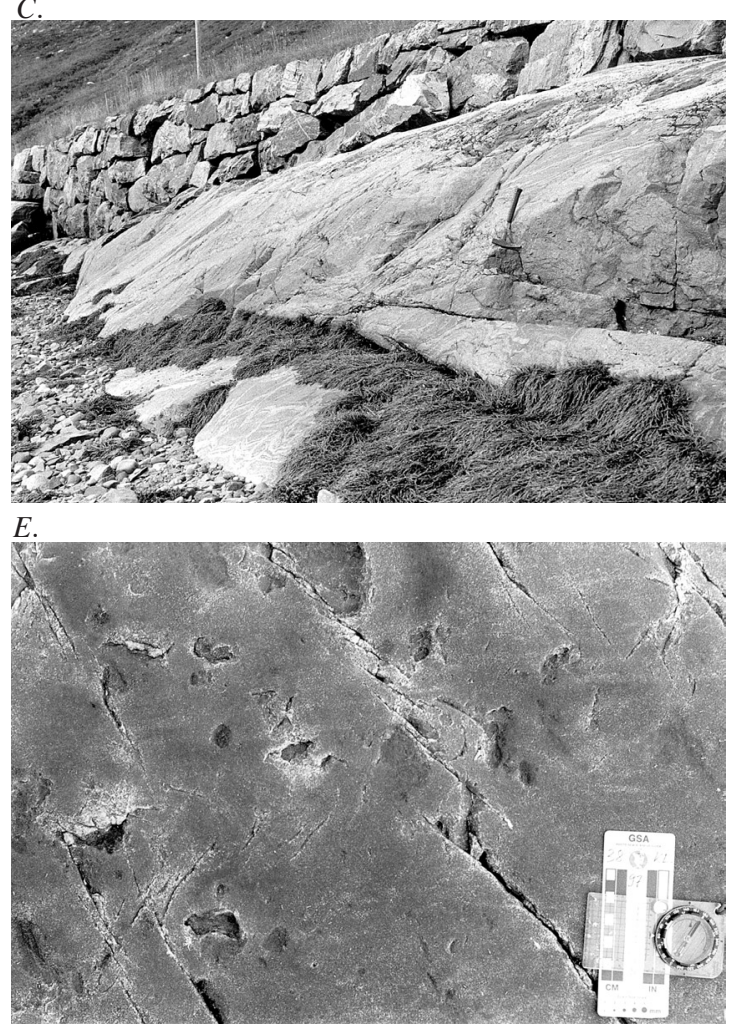

$B$.

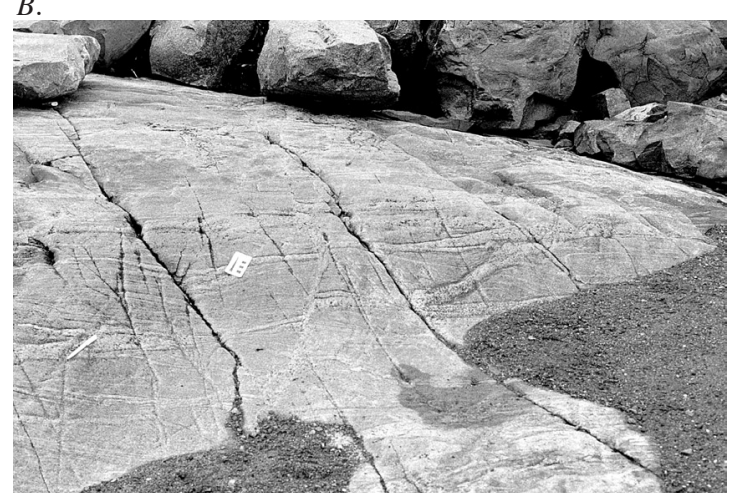

D.

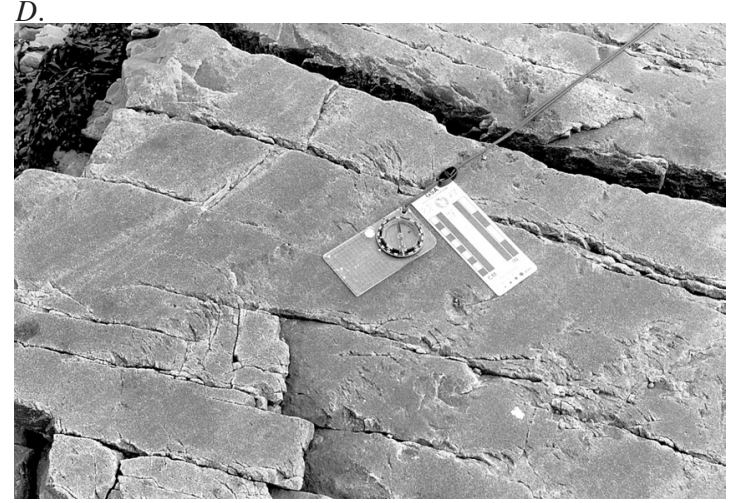

Fig. 6. Possible late Proterozoic roches moutonnées at Karlebotn (A-C) and Pleistocene striations on the Veinesbotn quartzite at Veinesbotn (D-E). Photos K. Laajoki. (A) A basement gneiss outcrop seen from the east. Note the smooth northern end of the outcrop (see B). Val933. (B) Close-up of the smooth northern end of the gneiss outcrop, with probable Pleistocene striations parallel to the pen and scale. Va19-32. (C) The southern part of a gneiss outcrop which may represent late Proterozoic roches moutonnées modified by the Pleistocene glaciation. Va19-35. (D) Pleistocene striations (parallel to the compass string) and crescentic fractures on the split erosional surface of the Veinesbotn quartzite (for location, see Fig. 5a). Photo Va2-9. (E) Strange pits of unknown origin on the same surface. Striations and crescentic fractures are only poorly visible. Photo Va2-8.

can be accepted. The ideas or suggestions of a soft-sedimentary origin for the surface advanced by the "non-glacial school" were based on circular reasoning which concluded that because the "Reusch moren" ( an early historical name of the Bigganjargga diamictite) was not a tillite but a mud flow, its pavement must have been soft, be- 
cause a mud flow cannot striate a hard rock. On the other hand, it is equally wrong to reason that the overlying rock is glacial because its pavement is glacial (cf. Edwards 1975, Spjeldnæs 1964). The author considers it possible that the Bigganjargga diamictite may not be a tillite but a debris flow. In this respect the "non-glacial school" may be right, but this has not yet been confirmed properly. The work of Jensen and Wulff-Pedersen (1996) provides a good opening in this respect.

As the VFU at Bigganjargga was formed on a hard rock, the notion of a soft-sedimentary origin for its pits and imprints can also be rejected.

The main open question concerning the VFU is the direction of flow of the ice that abraded it. It is generally accepted that the ice came from the south or southeast, but we do not have any direct evidence of this. If the presumed roches moutonnées at Karlebotn are Proterozoic in age, it is possible that the ice flow came from the opposite direction at least when these forms were created.

ACKNOWLEDGEMENTS. Permission from the Environmental Department of the Regional Commissioner of Finnmark to collect samples and clean up the algae-covered part of the Bigganjargga outcrop is gratefully acknowledged. About two weeks of fieldwork was carried out in the summers of 1997 and 1999, when the author was a visiting NorFA professor at the University of Oslo. The paper is a contribution to the project "The Significance of Exogenic Processes for the Development of the Precambrian Crust" led by Prof. Tom Andersen, University of Oslo, and the Academy of Finland project "Ore Processes and Geotectonics" led by the author. Useful comments and suggestions by Prof. Anna Siedlecka, an anonymous reviewer, and the editor are acknowledged. The English of the manuscript was revised by $\mathrm{Mr}$. Malcolm Hicks.

\section{REFERENCES}

Arnaud, E.V. \& Eyles, C.H. 1999. Identifying the sedimentological signature of a Neoproterozoic glaciation: the Smalfjord Formation, northern Norway. Geological Society of America. Abstracts with Program 31, A487.
Bates, R.L. \& Jackson, J.A. (eds.) 1995. Glossary of Geology. $3^{\text {rd }}$ edition. CD-edition. Alexandria: American Geological Institute.

Bjørlykke, K. 1967. The Eocambrian "Reusch Moraine" at Bigganjargga and the geology around Varangerfjord, northern Norway. Norges geologiske undersøkelse 251, 18-44.

Crowell, J.C. 1964. Climatic significance of sedimentary deposits containing dispersed megaclasts. In: Nair, A.E.M. (ed.) Problems in Palaeoclimatology. London: John Wiley \& Sons, 86-99.

Crowell, J.C. 1999. Pre-Mesozoic Ice Ages: Their Bearing on Understanding the Climate System. Geological Society of America, Memoir 192. 106 p.

Edwards, M.B. 1975. Glacial retreat sedimentation in the Smalfjord Formation, Late Precambrian, North Norway. Sedimentology 22, 75-94.

Edwards, M.B. 1984. Sedimentology of the upper Proterozoic glacial record, Vestertana Group, Finnmark, North Norway. Norges geologiske unders $\varnothing$ kelse, Bulletin 394. 76 p.

Edwards, M.B. 1997. Discussion of glacial or non-glacial origin for the Bigganjargga tillite, Finnmark, northern Norway. Geological Magazine 134, 873-876.

Harland, W.B. 1964. Critical evidence for a great infraCambrian glaciation. Geologische Rundschau 54, 45-61.

Harland, W.B. \& Rudwick, M.J.S. 1964. The great InfraCambrian ice age. Scientific American 211, 28-36.

Harland, W.B., Herod, K.N. \& Krinsley, D. 1966. The definition and identification of tills and tillites. Earth-Science Reviews 2, 225-256.

Hobday, D.K. 1974. Interaction between fluvial and marine processes in the lower part of the late Precambrian Vads $\varnothing$ Group, Finnmark. Norges geologiske undersøkelse 303, 39-56.

Holtedahl, D. 1918. Bidrag til Finmarkens geologi. Norges geologiske unders $\varnothing$ kelse 84. 311 p.

Jensen, P.A. \& Wulff-Pedersen, E. 1996. Glacial or nonglacial origin for the Bigganjargga tillite, northern Norway. Geological Magazine 133, 137-145.

Jensen, P.A. \& Wulff-Pedersen, E. 1997. Discussion of glacial or non-glacial origin for the Bigganjargga tillite, Finnmark, northern Norway. Geological Magazine 134, 873-876.

Laajoki, K. 1999a. Late Proterozoic glacial unconformity at Bigganjargga, Finnmark, Norway. EUG 10, March $28^{\text {th }}-$ April $1^{\text {st }}$, 1999, Strasbourg, France. Journal of Conference Abstracts 4, p. 732.

Laajoki, K. 1999b. Late Proterozoic glacial unconformity around Varangerfjorden, northern Norway. $19^{\text {th }}$ Regional European Meeting of Sedimentology, Copenhagen 2227 August 1999. Abstract Volume, p. 149.

Laajoki, K. 2002. New evidence of glacial abrasion of the late Proterozoic unconformity around Varangerfjorden, northern Norway. In: Alterman, W. \& Corcoran, P. (eds.) Precambrian Sedimentary Environments: Modern Approach to Ancient Depositional Systems. International Association of Sedimentologists, Special Publication 33, 405-436.

Laverdière, C., Guimont, P. \& Dionne, J-C. 1985. Les 
formes et les marques de l'érosion glaciaire du plancher rocheux: signification, terminologie, illustration. [Forms and marks of glacial erosion on bedrock: signification, terminology, illustration.] Palaeogeography, Palaeoclimatology and Palaeoecology 51, 365-387.

Nordkalott Project, 1986. Map of Quaternary Geology, Sheet 3: Ice Flow Indicators, Northern Fennoscandia, 1: 1000 000. Geological Surveys of Finland, Norway and Sweden.

Reusch, H. 1891. Skuringsmerker og morenegrus eftervist i Finnmarken fra en periode meget elder end "istiden". English summary: Glacial stria and boulder-clay in Norwegian Lapponie from a period much older than the last-ice age. Norges geologiske unders $\varnothing$ kelse 1, 7885 and $97-100$.

Rice, A.H.N. \& Hofmann, C.-C. 2000. Evidence for glacial origin of Neoproterozoic III striations at Oaibaččannjar'ga, Finnmark, northern Norway. Geological Magazine 137, 355-366.

Rosendahl, H. 1931. Bidrag til Varangernesets geologi. Norsk geologisk tidsskrift 12, 487-506.
Rosendahl, H. 1945. Praekambrium-Eokambrium i Finnmark. Norsk geologisk tidsskrift 25, 327-349.

Schermerhorn, L.J.G. 1971. Upper Ordovician glaciation in northwest Africa? Discussion. Geological Society of America, Bulletin 82, 265-268.

Schermerhorn, L.J.G. 1974. Late Precambrian mixtites: glacial and/or nonglacial. American Journal of Science 274, 673-824.

Siedlecka, A. 1990. Varangerbotn berggrunnskart 23353 , 1: 50 000, föreløpig utgave. Norges geologiske undersøkelse.

Siedlecka, A. 1991. Nesseby berggrunnskart 2335 2, 1 : 50 000, föreløpig utgave. Norges geologiske undersøkelse.

Siedlecka, A. \& Roberts, D. 1992. The bedrock geology of Varanger Peninsula, Finnmark, North Norway; an excursion guide. Norges geologiske unders $\emptyset$ kelse, Special Paper 5. 45 p.

Spjeldnæs, N. 1964. The Eocambrian glaciation in Norway. Geologische Rundschau 54, 24-45. 